CATALLAXY

Volume 6 Issue 1 June 2021

e-ISSN 2544-090X

C www.catallaxy.pl

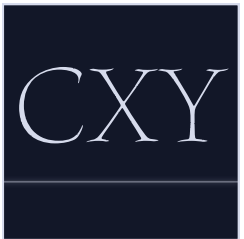

Original article

received: 10.11 .2020 / accepted: 26.04 .2021 / published online: 30.06 .2021

Grabowska-Powaga, A., \& Kamińska, M. (2021). Institutional factors creating labor market in Poland: the case of social capital. Catallaxy, , 6(1), 7-17. https://doi.org/10.24136/cxy.2021.001.

\title{
Institutional factors creating labor market in Poland: the case of social capital
}

\section{ALEKSANDRA GRABOWSKA-POWAGA}

corresponding author

University of Economics in Katowice, Faculty of Management, Department of Political Economy, ul. 1 Maja 50,

40-287 Katowice, Poland

\aleksandra.grabowska@ue.katowice.pl

(D) orcid.org/0000-0003-1694-6469

\section{MONIKA KAMINSSKA}

University of Economics in Katowice, Faculty of Management, Department of Political Economy, Poland

\monika.kaminska@uekat.pl

(D) orcid.org/0000-0003-1447-4920

\begin{abstract}
Motivation: Labor market in Poland has been affected by many institutional factors. One of them is social capital, which can be an advantage for its development It influences the ability among the market entities to cooperate with each other and to create their competitiveness on the market. The lack of social capital causes many disadvantages like the lack of ability to cooperate between different actors. That is why strong social capital is a challenge to build long term relations on the labor market. Low social capital or its lack is a barrier in country's development, weakens the markets, makes the markets impossible to improve in quality. On the basis of the above premises the main hypothesis of the paper claims, that the main barrier which limits the ability among different actors to create social capital on labor market in Poland is low level of trust to each other.

Aim: The main cognitive aim of this article is to describe the conducted primary research and identify determinants, especially threats and barriers on labor market in Poland in the points of views of different participants who take part in interactions with the other actors on the labor market (entrepreneurs, employees, employers).

Materials and methods: The research had a character of preliminary study. The main research methods used in this article include desk research and primary research with Individual In-Depth Interviews (IDI method) which were conducted among Polish entrepreneurs from March till June 2018 and from October till January 2019.

Results: The Respondents, who took part in the research underlined the importance of cooperation and social capital, but they also mentioned about barriers which reduce the level of cooperation and ability to create social capital.
\end{abstract}

Keywords: labor market; institutions; social capital; cooperation; trust JEL: J24; D02 


\section{Introduction}

Significance of labor resources in contemporary world is constantly growing. The very labor market must adapt itself to rapidly changing conditions of the environment, including globalization, growing competition, or progressing technologization and computerization of production (Frey \& Osborne, 2017, pp. 254-280; Goos et al., 2014, pp. 2509-2526). Labor market is one of basic concepts that are used in many research disciplines, and yet, it is not easy to define. It can be assumed in a simplified way that market is a form of establishing contacts between the seller and buyer that allows for determining the terms and conditions for transactions (they include price, quantity, place, and time of completion among others) that can be accepted by both parties to the transaction. Therefore, labor market is perceived as the sphere of establishing contacts and relations between the worker (who creates the supply of labor resources) and the employer (who represents the labor demand). Labor market is also understood as a network of relations between various actors who help to organize the labor market, i.e., institutions, workers, and employers. Labor is the object of exchange in the transaction, whereas its value is presented in the form of remuneration. It is a complex and open system whose operation is determined by external environment. All the working and pay conditions are determined through negotiations, in which the state plays an active role, through setting the minimum pay, termination of employment, or active policy of counteracting the unemployment. Institutions that have impact on the shape of the market, including institutions of social assistance, union trades or district labor offices are also in direct relationships with labor market. Labor supply, also defined as labor resources, in the broadest approach refers to the working age population that is employed or wants to find employment at a given time and on conditions observed in economy. The very size of labor supply is determined by many determinants of macro-economic, macro-social (demography, culture, organization) or micro-economic (behaviors of enterprises or households) character. On the other hand, demand on labor in macroeconomic approach is understood as the demand on workers that is declared by all the employers.

According to data from institutions monitoring labor market (GUS, BAEL, EUROSTAT), changes in this market in Poland over the last decade have been noticeable. They include a gradual decline in the unemployment rate a decrease in the rate of professionally inactive people, and an increase in the average gross salary or the minimum wage. Until the end of 2019, the situation on the labor market in Poland was the result of a continuous GDP growth at an optimal level, among others. Determinants shaping the work quality have also changed. They included socio-demographic factors (growth of migration that brought outflow of skilled labor force from domestic labor market among others), political determinants (increased subsidies within pursued social policy for people temporarily excluded from labor market among others) and economic determinants (for example growth of average remuneration in the national economy - in 2014 - PLN 3783, in 2019 - PLN 5169 among others) (comp. Table 1). All these caused the shift of balance on the labor market towards the growth of demand and decline in supply till 2019. Due to the situation related to the spread of the pandemic caused by the SARS-CoV-2 coronavirus, in 2020 the trends in the studied area changed. The demand for labor decreased in many branches (Coibion et al., 2020, pp. 1-13). Since the beginning of the pandemic caused by SARS-CoV-2 the crisis has caused economic downturn, a decline in consumption demand and global supply, the closure of borders that prevented the inflow of migrants undertaking low-paid jobs, the introduction of remote work, which resulted in a lower demand on performance of on-site duties, an increase in the precariat, and a growth of the sense of insecurity among both the employers and employees. These are only a few changes also observed in the sphere of the labor market. Although today it is difficult to estimate the consequences of the observed 
changes in the labor market resulting from the crisis caused by the COVID-19 pandemic, the data concerning the possibility to achieve the situation on the labor market in Poland before 2020 (employment rates or unemployment rates) is not optimistic (comp. Table 1 ).

Due to the dynamic situation on labor market in Poland, such factors as motivating workers both by employers and colleagues, as well as the ability to cooperate and consequently to establish social capital on the micro-scale (for example within one organization) and on the macro-scale, and in this context, on the whole labor market have gained the key significance.

The above premises that are implications of conducted secondary research also became the stimulus for the authors to implement primary research. Its purpose was to describe the determinants for starting cooperation by entities on labor market and creating social capital on this market. That is why the authors took a decision to conduct the research concerning the determinants shaping the labor market in Poland and to identify the role of cooperation and social capital among all of the actors shaping the labor market. In 2018 and at the beginning of 2019 preliminary research was conducted. Ten Entrepreneurs were invited to take part in it. Using IDI method, the invited Respondents not only emphasized the importance of cooperation and the role of social capital in economic activities, but they also identified threats and barriers on labor market in Poland, that limit their abilities to connect relations, cooperate with other actors and to build social capital. The research had a character of preliminary study, but the discussion with the Respondents and the conclusions were so interesting and important, that they were worth presenting on this level of research. Currently the research is being extended and conducted on a larger group of actors on the labor market in Poland.

\section{Social capital: theoretical background}

Dynamic and unpredictable changes occurring in contemporary economies force bu- siness entities to adapt to revolving market conditions. Contrary to many classic economic theories the entities cannot operate absolutely rationally in real economic systems. Their rationality in market behaviors is limited by many factors. The character of information streams that reach them is one of these factors. Information asymmetry and dynamic nature of information streams bring unwillingness to take a risk. Therefore, they choose safe behaviors compliant with some routine that they acquire through procedural repetition of behaviors of the entities that proved to be successful, or through behaviors based on the vision of how other entities would behave. In other words, economic actors follow institutions that make their actions routine and the world more predictable. Institutions can directly and indirectly influence economic activity on each market (in this case also labor market) and the economic growth. When we speak about direct influence, we think of some economic incentives which are caused by institutions just like growth or drop of production's dynamics or turnovers which have impact on income and economic growth. Indirectly, the institutions can lead to investments' growth, better management in different conflicts, better politics, and social capital growth in a society. Both formal and informal institutions help entities to take decisions concerning for example economic activity, or they allow the entities to achieve planned goals. It is important, that institutions should be treated not only as some constraints but also as possibilities. Modelling behaviors based on experiences of other entities or on the images of these behaviors can prove ineffective or even impossible. In the face of risk and inability to repeat "verified market behaviors" the entities aim at establishment of relationships that often result in starting cooperation with other entities. Establishment of relationships between entities often has informal nature. Social capital is one of the informal institutions that emerged on the basis of established relationships, and is made of behaviors of entities, small groups forming networks of interaction and social institutions. Following the 
authors in literature social capital is the aggregate of the actual or potential resources which are linked to possession of a durable network of more or less institutionalized relationships of mutual acquaintance and recognition or in other words, to membership in a group - which provides each of its members with the backing of the collectively-owned capital, a 'credential' which entitles them to credit, in the various senses of the word (Bourdieu, 1986, p. 248; Coleman, 1998, p. S109; Fukuyama, 2001, p. 7; Grabowska-Powaga, 2019, p. 115; Ostrom, 2000, p. 176; Putnam, 1995, p. 258; Scrivens \& Smith, 2013, p. 9; Sztompka, 2002, p. 368).

Presented in literature definitions have one common feature; they all describe social capital as some kind of resource. Apart from traditional production factors such as land and work, and contemporary ones, e.g., knowledge, social capital is becoming an economic resource for entities in market processes. In the literature on the subject, social capital is not a homogeneous concept. Therefore, its various types can be indicated, including the following:

- bonding and bridging social capital are identified by the criterion of the coverage of relations;

- formal and informal social capital is identified by the criterion of formalizing the relationship;

- network and managerial social capital can be identified by the criterion of the ability to establish relationships;

- the network and share capital are defined by the criterion of the entities' access to resources.

Together with human capital and organizational capital it forms intellectual capital approached as human resources of entities in market processes. Sometimes it is also included in creative capital. Social capital, its scope, the growth of its potential or its complete inhibition is determined by occurrence of many factors, instruments, and tools. They are applied by appropriate entities, and their goal is to increase the social potential. The literature on the subject identifies the following groups of determinants that have impact on social capital (Czapiński, 2009, pp. 270-275; Golinowska, 2008, pp. 113-137; Grabowska-Powaga, 2019, pp. 138-149; Skawińska, 2012, p. 146; Wosiek, 2016, pp. 39-54):

- institutional factors: among them, attention should be paid to such environmental determinants of communities and societies as cultural and creative potential;

- conditions of political, social, and economic determinants such as income structure and social, as well as economic structure of the institutions.

Social capital plays nowadays an important role as an economic resource in transactions between entities on every market. Social capital as economic resource is gaining importance together with occurring unpredictability of material resources. Social capital productivity is the key to the development of national economies and the whole societies. It has endogenous nature and is mainly determined by the will and engagement of the very participants in market processes. While establishing relationships, they form social capital that is becoming a competitive resource in the struggle for market position. Social capital is also important on labor market; it plays a significant role in building cooperation among entities and has impact on its competitiveness (Cingano \& Rosolia, 2012, pp. 291-332).

Created on the basis of relations and cooperation between actors on the labor market social capital can ensure the continuity of economic and management processes where the state and its procedures fail. So social capital can fill the gaps in inefficiently working institutional mechanisms. It can also strengthen the bridging ties between the entities on the labor market that have not been related before (Grabowska-Powaga, 2020, pp. 37-45).

Nowadays social capital that we observe in Poland is not based on creativity, innovativeness, and activity of individuals for the benefit of good and community. According to some research social capital in Poland is low (Czapiński, 2013, pp. 285-297; Gajowiak, 2012, p. 124) and its level is rather an expression of survival and adaptation of individuals 
to new institutions. It can also be seen on the labor market. Therefore, it is so important to conduct research in this area and to present the results to increasingly larger groups of recipients.

In this article the authors try to emphasize some aspects concerning social capital on labor market on the basis of research, which was conducted in Poland, and focus on institutional determinants of creating social capital as perceived by labor market actors on microeconomic level.

\section{Materials and methods}

To recognize institutional determinants shaping the labor market, desk research and qualitative research in the form of individual in-depth interviews (IDI, in-depth interview) was conducted among selected group of entrepreneurs. Desk research was based mainly on the analysis of data from different organizations that deal with labor market in Poland. The qualitative research had a character of preliminary study. Of the 50 entrepreneurs invited to the study, ten responded to the invitation. The group of entrepreneurs represented micro and small enterprises which constitute the largest share of enterprises in Poland. The group that participated in the pilot study was not representative, but the conducted interviews provided important information on the trends in the labor market in Poland and became the basis for the next stage of primary research (currently in progress). However, the Authors considered the results of the pilot studies in the sphere of the role of social capital in the labor market so important that they decided to prepare the following article on their basis. The goal of the research was to identify determinants affecting establishment of cooperation between entities on labor market and, consequently, creation of social capital in Poland, and to verify the hypothesis which claims, that the main barrier which limits the ability among different actors to create social capital on labor market in Poland is the low level of trust in each other.
The preliminary research consisted of two parts. The first stage of research was conducted between March and June 2018 and the second stage between October 2018 and January 2019. The discussion guide in both parts comprised questions concerning the respondents' opinions about determinants shaping the present market and shaping cooperation between entities; it also concerned the role of social capital in building competitiveness of entities on the labor market. The difference between these two parts of the research was the subject of the interview: in the first one the Authors analyzed with the Respondents, the general determinants of functioning and organizing labor market in Poland. In the second part the authors asked the respondents about the meaning of social capital, level of cooperation and the ability to build social capital between the actors on the labor market in Poland. The interviews were conducted every time with 10 selected entrepreneurs who were representatives of companies of various size (micro or small enterprise) and business activity. The Respondents presented different economic sectors including trade, services, construction, or mixed types.

The interviews were between 50 and 130 minutes long, and after each study, they were regularly transcribed while maintaining possibly the most precise transcription of opinions of respondents, whereas during data analyses, coding techniques were used.

\section{Research results: challenges to labor market in Poland}

In the first part of the research, conditions which faced by entities functioning on labor market, both employers (entrepreneurs) and workers were analyzed. Financial factors that affect conducting business activity, and institutional factors (mainly on informal level such as for example trust in contractors) that imply the quality of established relationships that have impact on cooperation between entities, its character, the chance of survival of the 
company and creation of social capital were addressed.

Such a division into institutional and financial determinants allowed during interviews to identify constraints that impede functioning of entities on labor market. During the interviews, the respondents paid attention to many determinants that hamper their economic activity. These barriers can be generally divided into the following groups:

- financial barriers, including problems with timeliness and financial liquidity of the partners, they establish economic relations with;

- institutional barriers, on formal level, including little precise bylaws, regulations that change fast, uncertain law, and on informal level, interpersonal barriers, lack of the wish to cooperate and collaborate, mutual prejudices and the lack of confidence.

As regards financial issues, the respondents emphasized the problem of late payments and impact of legal increase of the minimum wage in Poland. While observing the situation on labor market, entrepreneurs unanimously concluded that increase of the minimum wage would slightly affect the business activity of their companies.

As regards institutional barriers, changing law and specific regulations are the determinants that affect behaviors of entrepreneurs in Poland. This thread was started with the question about the evaluation of the present work of institutions the respondents have contact with Central Statistical Office, Social Insurance Institution, Tax Office, State Labor Inspectorate and others specialist controlling institutions were most frequently mentioned. It can be stated that obtained results were surprising, because it was expected that the respondents would be more critical. However, only two people expressed a negative opinion while stating that Polish institutions obstruct business operations mainly through "very frequent changes, while few people can follow them" (small company, domestic business activity). Furthermore, the same respondent indicates "currently uncertain law (...) tax audits that are not announced and there are many more of them. They concern matters that are unimportant". Slowness and lack of understanding for the other party, for example "this is elementary lack of understanding that these officers do not understand that I have to work for them to be there, because if it were not for people like me, they would not be there, they would be redundant" is the issue widely commented by respondents (small company, regional business activity). There were also contrary views according to which Polish institutions are customer/entrepreneur oriented, for example "when I was registering (...) the partnership I was positively surprised. I was there at 2.50, the woman in the office told me they would help me fill in the application. Besides, I came there with a wrong form filled in (...). We finished at 3.05 but she told me it was their duty. No problem" (enterprise from the SME sector, domestic business activity) (the working hours finished at 3.00 - the researcher comment). The researchers also paid attention to the fact that it cannot be generally stated whether institutions create barriers, or they rather help entrepreneurs to function on market, because actually a lot depends on a specific person who works in the place.

It proves that despite negative opinions about some institutions, the respondents do not notice the need to improve them; they prefer to adapt, to be able to run their business activity without any obstacles. They appreciate the attitude of people working in institutions and generally it is most important for them.

In further part, during the interview, it was analyzed whether long-term planning was an important determinant in enterprise development, if it was affected by current economic situation of the state, introduced changes or new laws, and if it was, how much it affected the changes in planned company strategy. The respondents stated that they rather did not focus on the issues of problem solving or seeking consumers, but they deal with formalities and continuous adaptation to legislative changes.

In conducted interviews, identification of institutional determinants on informal level (including mutual trust, business ethics, co- 
operation enterprises, relations in the society) were also important. Therefore, the question about observed behaviors, correlations and relationships between entities that may have impact on creation of their competitiveness on labor market was also vital. Rather negative opinion of most respondents concerning reliability of entities with which they cooperate is an important signal coming from conducted research, especially in the context of the role of social capital on the labor market. The respondents often drew attention to unethical behavior of competitors and emphasized their lack of confidence in other companies. They indicated their own experiences in this sphere as the basis for negative opinions. The respondents' opinions proved that all of them had personal experiences concerning the lack of competences of the workers or contractors. Negative opinions of respondents also concerned establishment of relationships, and consequently cooperation with financial institutions. At the same time, the respondents emphasized that they were one of few enterprises that act ethically.

Some respondents stated that the conviction of other respondents about their own commitment and opinion about the lack of competences of others most probably result from the time they started their business. One of the respondents indicated that "managing directors often have problems that something must be done, and they say when it must be done, but they do not see how much work there is (...) A bigger problem is the fact that many companies started their activity in 1990s when everything was easily sold, when it was enough to create a product as it was easily marketable. Now competition is growing so they start to complain that everything is Chinese, that there are competitors from the West... Well, there are some mental barriers, they think they still function in these times".

On the basis of conducted research, some problems resulting from institutional determinants could be identified. They can become restraints to shaping social capital among entities functioning on labor market. Analyzing the respondents' opinions, the following problems faced by entities functioning on the labor market can be identified among others:

- dislike toward other companies and attributing negative features to them (for example unreliability, unethical conduct), which in result can bring the lack of confidence and willingness to establish relationships supporting closer cooperation;

- lack of confidence, which might be the result of financial problems faced by entities participating in business transactions;

- categorizing and valuation of workers by employers on the basis of their demographic features (often racially motivated), social features, etc.;

- conviction about own commitment and its lack at others;

- conviction about insufficient qualifications of workers, colleagues, and trading partners.

On the basis of the above responses the main hypothesis of the paper, which states, that the main barrier which limits the ability among different actors to create social capital on labor market in Poland is low level of trust in each other, can be verified positively.

However dynamic changes that occur in modern economy force the entities to adapt to the present conditions. Many entities approach rationally continuous changes while trying to establish cooperation and relationships as well as supporting each other. Growing awareness of both employers, contractors, and workers of the necessity to establish cooperation without which it is difficult to achieve defined targets and competitive position on market is an important information resulting from the research.

Changes occurring in modern economies force business entities to adapt to new conditions on the market of their functioning. Entrepreneurs are aware that social capital is a vital determinant that contributes to development of their company. The question of confidence of both parties to the relations was one of vital aspects of the research. Most respondents without being directed by the researcher, indicated confidence in others or others to their company as one of the key 
factors determining the trend of their activity. The very thread of confidence was rather surprising because the respondents on the one hand did not trust others, for example their workers, but were surprised that customers did not trust them.

As regards trust of the parties in the relationships on the labor market, the respondents admitted that while signing the contract of employment, they must trust each other that each party to the transactional relationships would obtain the terms and conditions negotiated during the interview (for example financial benefits for the worker such as remuneration, and social - appropriate status in the society resulting from the work, among others; the employer benefits resulting from labor productivity of the worker among others). The respondents admitted that sometimes they apply the tools "checking" workers' reliability through the use of appropriate programs e.g., monitoring the time of coming to work and leaving the workplace for home.

The issue of tools applied to establish contacts with other entities in market transactions was another example of the approach to trust. The respondents have a limited confidence in widely accessible Internet portals that enable market transactions e.g., allegro, OLX, eBay, etc. Online stores that are perceived as more reliable by the parties to the transaction enjoy greater trust. One of the respondents admitted that before, he had only sold on such portals as OLX which he actually did not fully trust. On the other hand, he perceived online store as something certain, secure, and trustworthy.

The research often discussed the issues of the skill of cooperation either from the perspective of the environment inside the company, i.e., the workers in the team, or from the perspective of the environment outside the company - entrepreneurs with each other, business, science, etc. In such situation the cluster institution is often applied. However, in practice there occur problems related to the lack of financial resources that would support such an initiative, organizational problems (including growing bureaucracy) and institutional (initially the willingness to establish cooperation between entities changes into reluctance to bear responsibility for common tasks and goals and distrust of entities that are oriented on individual interests rather than on acting in group.

To sum up, during the research the Respondents often mentioned how cooperation is important for them and for their business activities. They pointed how to strengthen the cooperation between the entities. For example they underlined the lack of activities which would be helpful to connect and strengthen the cooperation between different parties on the labor market, like: to create and promote cooperation centers, to offer dual studies for students who will have the opportunity to study and prepare for the needs of specific companies, to enable to establish cooperation with science and research, to create some workshops, meetings to promote the idea of cooperation and social capital (its role in the economic and social life). On the other hand, the Respondents also see the barriers because there are so many problems with cooperation and creating social capital on the labor market in Poland. The most important threat which reduces the cooperation is limited or sometimes even lack of trust, lack of responsibility in the cooperation's institutions like clusters, financial problems, lack of human capital and very often lack of awareness what advantages from the cooperation and social capital are.

\section{Conclusions}

The conclusions from the conducted research can be perceived as negative and positive in terms of cooperation and creating social capital.

Why is the need to cooperate and create social capital so weak on labor market in Poland? The problem of the lack of the ability to cooperate and the skill necessary to build the fundaments of social capital occurred in almost each interview. The reasons emphasized by the respondents included limited trust and lack of confidence which might be the result of financial problems faced by entities participating in business transactions, lack of the 
willingness to cooperate and achieve common goals which might be the result of conviction about own commitment and its lack at others, conviction about insufficient qualifications of workers, colleagues, and trading partners. The respondents also emphasized that they often needed a coordinator to establish cooperation between various entities operating on a given market (there is often a problem who leads and takes responsibility for cooperation).

The conclusion which seems to be positive in terms of the role of cooperation and social capital on labor market in the future is, that we can observe growing awareness of both employers, contractors, and workers of the necessity to establish cooperation without which it is difficult to achieve defined targets and competitive position on market.

The presented conclusions do not exhaust the problem defined in this paper, but they allow to verify positively the hypothesis, that one of the main barriers to connect the relations, to tie them, to cooperate and build social capital is still extremely low level of trust and confidence between actors on the labor market. The problem is important and has to be analyzed deepen, especially nowadays in the times of crisis caused by the COVID 19 when cooperation and social capital might help actors to survive the uncertainty times, not only on the labor market, but in each sphere of economic and social life.

\section{References}

Bourdieu, P. (1986). The forms of capital. In J.G. Richardson (Ed.), Handbook of theory and research for the sociology of education (pp. 241-258). Greenwood Press.

Cingano, F., \& Rosolia, A. (2012). People I know: job search and social networks. Journal of Labor Economics, 30(2), 291-332. https://doi. org $/ 10.1086 / 663357$.

Coibion, O., Gorodnichenko, Y., \& Weber, M. (2020). Labor markets during the Covid-19 crisis: a preliminary view. NBER Working Paper, 27017, 1-13. https://doi.org/10.3386/w27017.

Coleman, J.S. (1998). Social capital in the creation of human capital. American Journal of Sociology, 94, S95-S120.
Czapiński, J. (2009). Stan społeczeństwa obywatelskiego: kapitał społeczny. In J. Czapiński, \& T. Panek (Eds.), Diagnoza społeczna 2009: warunki i jakość życia Polaków (pp. 270-280). Retrieved 15.03.2021 from http://www.diagnoza.com.

Czapiński, J. (2013). Stan społeczeństwa obywatelskiego: kapitał społeczny. Contemporary Economics, 7(4), 285-297. https://doi.org/10.5709/ ce.1897-9254.110.

Frey, C.B., \& Osborne, M.A. (2017). The future of employment: how susceptible are jobs to computerisation. Technological Forecasting and Social Change, 114, 254-280. https://doi.org/10.1016/j.techfore.2016.08.019.

Fukuyama, F. (2001). Social capital, civil society and development. Third Word Quarterly, 22(1), 7-20.

Gajowiak, M. (2012). Kapitat społeczny: przypadek Polski. PWE.

Golinowska, S. (2008). Wykluczenie społeczne. In S. Golonowska (Ed.), Od ubóstwa do wykluczenia społecznego: badania, koncepcja, wyniki, propozycje Polska Europa i Świat (pp. 113-137). IPISS.

Goos, M., Manning, A., \& Salomons, A. (2014). Explaining job polarization: routine-biased technological change and offshoring. American Economic Review, 104(8), 2509-2526. https:// doi.org/10.1257/aer.104.8.2509.

Grabowska-Powaga, A. (2019). Kapitat spoteczny a gospodarowanie: aspekty teoretyczne i empiryczne. CeDeWu.

Grabowska-Powaga, A. (2020). The role of social capital in economic activities in Poland in the period of global crisis. Prace Naukowe Uniwersytetu Ekonomicznego we Wroctawiu, 64(7), 37-45. https://doi.org/10.15611/pn.2020.7.03.

Macroeconomic Data Bank. (2021). Retrieved 15.03.2021 from https://bdm.stat.gov.pl.

Ostrom, E. (2000). Social capital: a fad or a fundamental concept. In P. Dasgupta, \& I. Serageldin (Eds.), Social capital: a multifaceted perspective (pp. 172-214). The World Bank.

Putnam, R. (1995). Demokracja $w$ działaniu: tradycje obywatelskie we wspótczesnych Włoszech. Znak.

Scrivens, K., \& Smith, C. (2013). Four interpretations of social capital: an agenda for measurement. OECD Statistics Working Papers, 2013/06, 1-70. https://doi.org/10.1787/5jzbcx010wmt-en.

Skawińska, E. (Ed.). (2012). Kapitał społeczny w rozwoju regionu. PWN.

Sztompka, P. (2002). Sociologia: analiza spoteczeństwa. Znak. 
Wosiek, M. (2016). Kapitał społeczny w kontekście nierówności ekonomicznych: wybrane aspekty teoretyczne. Optimum. Studia Ekonomiczne, 2(80), 39-54. https://doi.org/10.15290/ ose.2016.02.80.04.

Acknowledgements

Author contributions: authors have given an approval to the final version of the article. Authors contributed to this work equally.

Funding: this research was fully funded by the author's own sources.

Note: the results of this study were presented at 10th International Conference on Applied Economics Contemporary Issues in Economy (June 27-28, 2019, Toruń, Poland). 


\section{Appendix}

Table 1.

Labor Market in Poland in 2014-2020: selected indexes

\begin{tabular}{lrrrrr}
\hline \multicolumn{1}{c}{ Index } & 2014 & 2016 & 2018 & 2019 & 2020 \\
\hline people in general (thous.) & 38484 & 38437 & 38412 & 38383 & 38268 \\
professionally active (thous.) & 17428 & 17282 & 17058 & 16940 & 17224 \\
professionally inactive (thous.) & 13543 & 13414 & 13353 & 13300 & 13041 \\
unemployment rate (\%) & 11.5 & 8.3 & 5.8 & 5.2 & 6.1 \\
average remuneration & 3980 & 4277 & 4852 & 5169 & 5484 \\
minimum remuneration & 1680 & 1850 & 2100 & 2250 & 2600 \\
\hline
\end{tabular}

Source: Own preparation based on Macroeconomic Data Bank (2021). 
